Славко В. ПЕТАКОВИЋ ${ }^{*}$

Универзитет у Београду

Филолошки факултет
Оригинални научни рад

Примљен: 24. 11. 2016.

Прихваћен: 10. 02. 2017.

\title{
ДУБРОВНИК У ЕСЕЈИМА ЛУЈА ВОЈНОВИЋА
}

\begin{abstract}
У раду се разматрају тематско-стилске карактеристике есеја Луја Војновића сабраних у књизи Књижевни часови (1912). Ови есеји су парадигматични примери особеног стилског и научног обрасца многих Војновићевих студија и монографија посвећених дубровачкој историји и књижевности. У раду се анализира како је аутор, бавећи се књижевним и друштвено-историјским темама, у широком распону од есеја о Гундулићевом Осману до осветљавања повесних прилика у Дубровачкој републици током векова, успоставио културолошку слику старог Дубровника, контрастирајући је са представом о Граду у савремености. Осветљавају се елементи специфичне стилске концепције есеја, засноване према аутопоетичком исказу Војновића на „пластичности језика и сликовитом приказивању грађе”, тј. на рафинираној књижевнонаучној ерудицији. Осим овога, у раду се разматрају и ауторови погледи на значај дубровачке традиције за српску и јужнословенску културноисторијску баштину.
\end{abstract}

Кључне речи: есеј, Лујо Војновић, Дубровник, историја, књижевност.

По много чему је Лујо Војновић несвакидашња појава у књижевности - између осталог и стога што је хваљен као утанчани стилиста и уметник (Черина 1912: 158) ${ }^{1}$, мада, строго гледано, лепој књижевности припада најмањи део његовог опуса, будући да је по основној вокацији био историчар и дипломата. Осим овога, ванредна је у литератури и заједничка појава Луја и његовог брата Ива, чија су дела тематски умногоме комплементарна и стилски прочишћена толико да су критичари истицали узорни начин писања „каквим у нашој литератури владају само кнежевска браћа Војновићи” (Ујевић 1965: 53). За разматрање уметничког поступка Луја Војновића можда и најпарадигматичнији пример представљају његови есеји, микромодели унутар којих је аутор полазећи од ужих тема брусио стилогене нијансе свога проседеа и композиционо усложњавао прилоге, од ситнијих до најзахтевнијих синтетичких огледа исказујући се као „ерудит и умјетник књижевности у најбољем складу" (Ујевић 1965: 75).

\footnotetext{
*petakovics@yahoo.com

${ }^{1}$ Видети и попис чланака у којима су дате сличне оцене у: Донат 1980: 23.
} 
У монографији Книжевни часови сабрано је десет Војновићевих историјских есеја - како се сводно и најпрецизније жанровски могу одредити прилози обухваћени књигом. Иако тематски разноврсни - посвећени одређеним историјским личностима, књижевним појавама, крупним историјским догађајима и монографијама написаним о њима - обједињени су, према пишчевом исказу ,јединственошћу мисли” (Војновић 1912: 5). У есејима се назиру темељи стилског и научног обрасца Војновићевих каснијих студија. Своју историографску методологију, види се у Кюижевним часовима, он је засновао на брижљивом проучавању извора до детаља, потом на тумачењу узрочно-последичног реда у историјским збивањима и извођењу замашних закључних синтеза о смислу повесних догађаја. Сам Војновић свесно је изграђивао посебан стил и своје схватање стваралачког идеала је на неколико места фиксирао, усредсређујући се најчешће на поетичке карактеристике историографског „писма”. Верујемо, међутим, да се његови назори о историографији имплицитно односе и на књижевност јер ове области није суштински разлучивао. Његово спознавање финог сазвучја књижевности и историје открива се и у насловној синтагми књиге (,књижевни часови”) којом је сабрао есеје. Једну рефлексију о историографији, посредно и о књижевности, језгровито је сажео исказом да је „облик [...] половина успеха” (Војновић 1912: 210). Следствено томе, све историјске студије Војновић је специфично конципирао, заснивајући их на уверењу да су „пластичност [...] језик и сликовито приказивање грађе" иманентна обележја историографског дискурса јер историја „није само наука него још и највећа вештина” (Андрић 1989: 116). Осим овога, схватање да се историја, тј. историографија, природно прожима са књижевношћу, посредно се ишчитава из оцене коју је дао у есеју „Један испит савјести" о монографији Стојана Новаковића Срби и Tурци XIV u XV века: „У нашој кьижевности (курзив је наш) никада се још нијесу чуле достојанственије и оштрије ријечи, никада праведнијег суда о једној народној катастрофи” (Војновић 1912: 211). Сличну повезницу успоставио је разматрајући историографске изворе о Маричкој бици, међу којима је издвојио сведочанство патријарха Пајсија. Уочио је и истакао литерарни карактер дела хвалећи динамичност дескрипције и „особиту силу и пластичност у писању [...]”. На основу увида у Пајсијево дело, али несумњиво и на основу доброг познавања српске средњовековне књижевне традиције, Војновић је потом дао оцену о нашој старој књижевности, полемички реагујући на уврежени негативни суд о њеној уметничкој вредности: „Толико презрена књижевна оставштина српска XIV вијека чини нам се напротив да стоји на великој висини за оно вријеме и оне околности” (Војновић 1912: 191).

И на другим местима у Кьижевним часовима указивао је аутор на специфичну повезаност историје и књижевности. Нарочито је у српској повести налазио теме за које је веровао да су достојне књижевне обраде. Сматрао je, на пример, да је удаја Оливере, кћери кнеза Лазара, за Бајазита изузетан догађај неисцрпног литерарног потенцијала јер „у цијелој повијести Балканског Полуострва нема трагичнијег догађаја”. Осим овога, српску средњовековну историју доживљавао је као јединствени пример јер је „српски народ 
доживио у сто година све фазе величанства и понижења. Опојио се сјајем царског вијенца $[\ldots]$ и предао је [...] једну своју кнегињу турском Султану за жену. Овакве драматске историје, у којој се измјенице удружују блистави оризонти и смртне сјени, није доживио ни један словенски народ” (Војновић 1912: 199, 201). И пораз српске војске у боју на Косову, судбоносан за читаву Европу („Пропаст Србије биће знак мртвачког звона, чији ће се далеки таласи мало по мало разлити и чути у Будиму и у Млецима, у Бечу и на острву Роду, у Кандији и на светом Готарду, у Напуљском заљеву и на далматинској обали”, Војновић 1912: 196), историјски је чин, према Војновићевом уверењу, достојан да буде овековечен уметничком транспозицијом повесне подлоге. У светлу овог исказа знаковит је суд Луја Војновића о уметничкој вредности опуса његовог брата Ива. Ставове Јована Скерлића и Павла Поповића, који су највише ценили Ивове драме Дубровачку трилогију и Еквиночиј, сматра Лујо Војновић заблудом јер је „централно” и „најгенијалније” дело његовог брата драма Смрт Мајке Југовића (Андрић 1989: 114).

Занимање за српску историју аутор Кюижевних часова је исказао у више есеја. Оно је било и природно јер, будући највише усредсређен на повест свога Дубровника, није могао заобићи повлачење историјских паралела са приликама у Србији, са којом је град Светог Влаха вековима био у тесним везама: „његова [односи се на Дубровник - прим. аут.] је повијест за четири пуна вијека знаменита чест политичке повијести српског народа. Богатство је Дубровника богатство српскијех земаља" (Војновић 1912: 180). Један од лајтмотива у Кюижевним часовима, знаковито је - и у Дубровачким елегијама, којима се Војновић појавио у свету књижевности, представа је о раскиду „новог” и „старог” времена. У контексту тог опозитног комплекса успостављена је паралела између Дубровника и Србије. Крај „старог” времена, обележеног идеалима и високим етичким и моралним вредностима, темпорално се подудара у дубровачкој историји са крајем Републике, а у Србији са другом половином деветнаестог века. У Дубровнику је то време „профанације”, а у Србији доба „Организације” које је наступило након „Револуције”, тј. пошто је минуо устанички талас, уступајући место дипломатском тактизирању са великим силама:

Али мину доба Револуције и настаде доба Организације. Она је морална попутина недостојна мучном грађењу друштва и државе. Гусла изгуби чар, постаде анакронизам. Српски се народ наједном нађе опасан погибељнијем свијетом него ли је био онај од кога се бјеше ријешио.

Говорећи о „новом” добу у српској историји, подсећа Војновић на речи Виолет ле Дука да цивилизација руши као и варварство, само се рушењем не хвали, и додаје:

А ми бисмо рекли да ова цивилизација која нас одасвуд паше, и руши и да се рушевинама хвали. Српски се народ одасвуд и одавна спотиче на ту организацију која у обили „сфере интереса” и „државнијех идеја” дубе [...] попут онијех америчких термита од којијех у један мах исцрвоточен брод потоне усред Оцеана (Војновић 1912: 213). 
И управо, поентира Војновић, Србија у будућности треба да се обнавља користећи се искуством Дубровника, који је столећима одолевао историјском ковитлацу:

... да учи из опустјелога Двора [...] живљети у смислу једне трајне државне радње, не ступати опчињени прошлом славом, него користити се погрешкама, рачунати са чињеницама и приправљати се скромно и умјерено, у видјелу с висине на пространу државну радњу (Војновић 1912: 214).

Најаутентичније примере историјског искуства Војновић налази управо у прошлости Дубровника, који је за њега ненадмашан споменик вишевековне историје, али и митопоетско чвориште, пупак културног света Европе. Град, ослоњен на копнени оковратник сурих стена и загледан ка јадранском хоризонту, осим што има специфичан географско-политички положај, обремењен је у прошлости јединственом културолошком традицијом, учвршћеном на размеђу Запада и Истока. Он је за Војновића орбитално средиште које одређује меру осталим појавама и засебна цивилизација унутар других светова („на длану руке носи цјелу једну цивилизацију”). Град Светог Влаха је сведок историјских седимената, материјално сведочанство колективног духа који се огледа у испосничком самопрегору његових житеља, у беспримерној жилавости и довитљивости генерација Дубровчана који су испољавали високу свест о дужности према отаџбини, не скривајући своју, Медитераном и копном разглашену, гордост којом су са висине осматрали страни свет. Упознавање и разумевање феномена дубровачке традиције могуће је тек стрпљивим урањањем у његову повест, студиозним проучавањем - „Али да се узмогне корисно прегледати, треба је прије познавати у детаљима, јер ниједна историја није тако пуна епизода и 'ситница' како је дубровачка" (Војновић 1912: 85) - методологијом коју у својим прилозима показује Војновић.

У есејима из Книжевних часова прожимају се путопис, анегдота, предање, наводе се документи, анализирају и убедљиво интерпретирају историјске чињенице кроз живо приповедање, које аутор подешава тако да се чини да су он и читалац у особеном спрегу - Војновић у улози учесника, а читалац у положају сведока „догађања повести”. Аналогија приповедном поступку могла би се наћи у сликарској техници кјароскуро (chiaroscuro) тонирања платана, којом се кроз игру светлости и сенке постижу одређени ефекти на визуелном и иконичком плану композиције. Светлим тоновима упризорује се ретко савремени Дубровник. Најчешће је представљен сфуматом пејзажа природе у приморју чија стилизација снажно кореспондира са дескриптивном топиком Дубровачких елегија (Петаковић 2016: 99-106). Позитивна слика Дубровника у прошлости успостављена је специфичном представом топографије самог Града или негдашње Републике, као и портретима знаменитих Дубровчана. Проткивање пасажа ерудитно-повесног карактера дескриптивним сегментима стилски је манир Војновићевог приповедања настао, како би то сам писац можда рекао, уношењем „малијех слика пунијех свјеже поезије” у научни дискурс. Неретко и сам аутор сугестивно указује на важност литерарних пасажа у ткиву историографске нарације. Анегдотску дигресију укључену у есеј о дубровачким поклисарима, на пример, назива поезијом високе вредности: 
„Вјерујте ми да ова мала пјесма вриједи за три Гундулићеве драме и за двије комедије Марина Држића.” (Војновић 1912: 25).

Град пишчеве савремености најчешће је представљен тамним бојама, контрастивно према слици Дубровника у прошлости, чиме се наглашава раскорак између негдашњег и садашњег. Колоритно-симболичка (дис)хармонија светло : тамно, некад : сад знаковито је појачана лирско-ироничним опозитом у стилизацији исказа. Приповедајући о подизању Дубровника, аутор понесено бележи:

Подигоше баш тамо на дрхтајима пучине, а на ждријелу варварскога свијета мали бијели стан, са којега ће да слободно и далеко од потресних звекетања оружја, шиљати миомирис поезије и лахор мора суровим заробљеним свијетовима, жртвама сабље, жртвама злобе, жртвама испразних фраза. Тако је постао Дубровник.

Насупрот оваквом тоналитету поставља резигнацијом осенчену проспективну секвенцу повести Града: „тмасти се будућност [...] не видим прелаза, него скока у тмину”. Јер, кобни расап идентитета неминован је услед губљења континуитета са традицијом, што иронично истиче Војновић посматрајући Дубровник: „Ту је смрт завладала посве демократски, по своме обичају" (Војновић 1912: 37, 15).

Супротстављајући лепоти природног пејзажа представу о савременом Дубровнику, Војновић на две равни проговара о судбини културе у олујној тмини историје. Физичко пропадање Дубровника, скрнављење и пљачкање гробова властеле, разарање бедема у Граду и околини, брутално архитектонско преосмишљавање древног амбијента, урбаног језгра и периферије - све је то „профанација”, „грозна профанација”, „бечка профанација”, дело „домаћих поамериканчених варвара" - дугачак је низ инвектива, нијансираних у зависности од означеног виновника. Растакање древне архитектуре Града, које Војновић сугестивно евоцира, претходи коначном удару на есенцијално упориште једног света - на културу, чија постојаност је нагризена меркантилистичком тамом савременог доба у коме су функционалност и профитабилност критеријуми на основу којих се руши и гради, затире и устоличава. Улицама Града се - досеже кулминацију Војновићева осуда изневеравања традиционалних обичаја и система вредности у Дубровнику - „излијевају садашња ситничарска, перцентуална, антиестетичка покољења. Нема ни једне једине профанације прошлости, коју опћина града Дубровника не би била дозволила”, „сви се завјерише да отаџбини Гундулића и Бошковића отму чар индивидуалности и да је провргну у експериментално поље бечкијех фирма и обогаћенијех 'Американаца"' (Војновић 1912: 162, 165).

Непосвећени читалац би у наведеним редовима наслутио тек наивну интерпретацију романтичарске идеје о „чистоти” фолклорне, гусларске културе која је угушена продором савремене цивилизације у Србији, или идеализацију конзервативно-аристократског система вредности над чијом пропашћу у Дубровнику ламентира аутор. Иза ове варљиве копрене се, међутим, открива далеко сложеније пишчево промишљање крупних друштвених феномена. 
Аутор Књижевних часова испољава чврсто уверење о важности историје за националну културу. Истиче да историја, тј. историографија, као сведочанство прошлости има велики значај, нарочито на нашем поднебљу, будући да ,jе заиста пуно важнија наука за нас него ли за велике народе [...] Јер ови велики народи носе у себи толико материјалне и моралне силе нагомилане редом вијекова [...] да и само понављање историчкијех заблуда није кадро да уздрма основе на којима почива њихов државни организам" (Војновић 1912: 173-174). Склони смо пак да смисао наведеног пасажа проширимо и на поље књижевности будући да, као што је већ речено, Војновић историографију и књижевност није децидно одвајао. Тумачење Војновићевих назора о релацијама историје и књижевности усложњава се узимањем у обзир још једног друштвеног феномена, трећег темена симболичке платформе на коју је ослоњена национална култура. То је феномен који Војновић назива дипломатијом. Њу на специфичан начин повезује са историјом и историографијом, посредством њих и са књижевношћу, у склопу потребе за јединственим деловањем на широком социо-културном фронту. Размишљајући о суштини историје, Војновић у неколико наврата парафразира прећутно или упућује отворено на Тенову идеју да „историја није ништа друго него психологија у акцији” и варира је: „[...] што је дипломатија него психологија примијењена на јавне послове" (Војновић 1912: 62, 239). На основу такве мисаоне окоснице отвара се дубљи увид у суштину Војновићег односа према свеколикој култури. Може се закључити да он свој есејистички рад доживљава као сведочанство историјског искуства на коме се заснива мудрост друштвене заједнице. У таквим релацијама позиција аутора историјских огледа је сложена. Он је преносилац и тумач древне мудрости, који специфичном стваралачком алхемијом мора чињенице да претвори у сугестивну материју, тј. има задатак да створи историографско-литерарно дело уравнотежујући однос фактографско-научног и уметничког, и да то дело положи у темеље националног културног обрасца. Методолошки модел који је засновао Војновић у есејистици био је ваљан, па су критичари хвалили његове прилоге, истичући да су „по садржини [...] наука” и „по изразу [...] умјетност” (Ујевић 1965: 75).

Есеји Луја Војновића садрже својеврсни поетско-филозофски супстрат његових размишљања о повесном усуду Дубровника, али и о смислу историје и односу историографије, уметности/књижевности и културе. Приказивање урушавања Дубровника као материјалног споменика у Кюижевним часовима симболички упућује на разарање ауре која отелотворава духовно језгро. Таквом корелацијом универзализовани су значењски слојеви и успостављена ,јединственост мисли” у есејима - као што је наглашено у предговору књиге. Успон и пад Дубровника, који је фундаментална парадигма Војновићевог погледа на историјска збивања и цивилизацијске токове уопште, повесни је садржај, чији смисао треба да одгонетне наука, фиксира потом у заједничком памћењу историографско-уметничка и уметничка интерпретација, формирајући стабилне друштвене обрасце, тј. знаковни систем који се познаје, у који се верује и који се генерацијски преноси (Герц 1998: 19-20 и даље). Највећа одговорност, убеђен је Војновић, за успостављање и 
одржавање културне парадигме, оријентира колектива у спознавању себе и свога места у свету, на плећима је националне интелектуалне елите. И њој се, суштински, обраћа аутор Кюижевних часова, очекујући да акумулирано повесно знање о материјалној и духовној баштини своје заједнице искористи посебном „дипломатијом” - речју Војновића, у сврху промишљене културне и јавне политике.

\section{ЛИТЕРАТУРА}

Андрић 1989: Н. Андрић, Разговор Бранимира Ћосића са Лујом Војновићем. Необјављене белешке, Београд: Прилози за књижевност, језик, историју и фолклор, LIII-LIV, 1987-1988, 104-116.

Војновић 1912: L. Vojnović, Književni časovi, Zagreb: Naklada knjižare Mirka Breyera.

Војновић 1924²: Л. Војновић, Дубровачке елегије, Дубровник: Издање књижаре J. Тошовића.

Герц 1988: K. Gerc, Tumačenje kulture, I, Beograd: Čigoja štampa.

Донат 1980: B. Donat, Lujo Vojnović, y: Pet stoljeća hrvatske književnosti, 63/I, Zagreb: Nakladni zavod Matice hrvatske, 7-23.

Петаковић 2016: С. Петаковић, Поетизовање историјске потке у „Дубровачким елегијама" Луја Војновића, Београд: Научни састанак слависта у Вукове дане, 45/2, 99-106.

Ујевић 1965: T. Ujević, Sabrana djela, knj. 7, Zagreb: Znanje.

Черина 1912: В(ладимир) Ч(ерина), Лујо Војновић „Књижевни часови”, Босанска вила, 10, 158.

Slavko V. Petaković

DUBROVNIK IN LUJO VOJNOVIĆ'S ESSAYS

(Summary)

While evoking a wide-ranging idea of Dubrovnik which he considered a fundamental paradigm of historical events and civilisational currents in Europe, in Literary Hours Lujo Vojnović represented a particular poetical-philosophical essence of his thoughts on the City's historical destiny. He also reflected on the meaning of history and the relation between historiography, art/literature and culture. Writing the historical essay, based on a refined erudition in literary scholarship, he established its poetics and paved its way in our literature and historiography. Vojnović highly valued this essay type, which in its own way synthesised the accumulated historical knowledge of a community's material and spiritual heritage. He considered the historical essay to form specific patterns, or spiritual landmarks of national culture. 